\title{
BRAF V600E Negative
}

National Cancer Institute

\section{Source}

National Cancer Institute. BRAF V600E Negative. NCI Thesaurus. Code C153163.

An indication that expression of the BRAF V600E mutation has not been detected in a sample. 